\title{
ANALISIS TEKNOLOGI LABORATORIS TEMBIKAR DARI SITUS GUA BULU SUMI, KABUPATEN PANGKEP, PROVINSI SULAWESI SELATAN
}

\author{
The Laboratory Technology Analysis of Pottery from Bulu Sumi Cave Site, \\ Pangkep District, South Sulawesi Province
}

\author{
M. Fadhlan S. Intan \\ Pusat Penelitian Arkeologi Nasional \\ Jl. Raya Condet Pejaten No. 4 Jakarta Selatan 12510, Indonesia \\ geobugis@yahoo.co.id
}

Naskah diterima: 26/01/2017; direvisi: 10/04-09/06/2017; disetujui: 15/06/2017

Publikasi ejurnal: 29/06/2017

\begin{abstract}
Pottery in Indonesia is one of the objects that plays an important role in people's lives from prehistoric times to the present. Pottery is one of the remains of cultural objects most commonly found in archaeological research, made of clay and burned. Analysis of pottery laboratory technology aims to obtain accurate data about the function and quality of a pottery. The method used is physical analysis and chemical analysis (gravimetry).Based on the results of laboratory technology analysis, the pottery from Bulu Sumi Cave Site included in the category of daily equipment that serves to hold water, process food, serving food and beverages. In terms of quality, the pottery, including in the medium to good quality, with a burning rate of $500^{\circ}-600^{\circ}$ Celsius and burned in open air.Color fragments of pottery, dominated by light colors compared with dark colors. Light colors due to the mineral content of quartz, and plagioclase that much on raw materials
\end{abstract}

Keyword: Bulu Sumi Cave, Pottery, Laboratory Analysis Technology

\begin{abstract}
Abstrak
Tembikar di Indonesia merupakan salah satu benda yang memegang peranan penting dalam kehidupan masyarakat dari masa prasejarah hingga masa kini. Tembikar merupakan salah satu sisa benda budaya yang paling sering ditemukan dalam penelitian arkeologi, terbuat dari tanah liat dan dibakar. Analisis teknologi laboratoris tembikar bertujuan memperoleh data yang akurat tentang fungsi dan kualitas dari suatu tembikar. Metode yang digunakan adalah analisis fisik dan analisis kimia (gravimetri). Berdasarkan hasil analisis teknologi laboratoris tersebut, tembikar-tembikar dari Situs Gua Bulu Sumi termasuk dalam kategori peralatan sehari-hari yang berfungsi untuk menampung air, mengolah makanan, penyajian makanan dan minuman. Dari segi kualitas, tembikar-tembikar tersebut, termasuk dalam tingkat kualitas sedang hingga baik, dengan tingkat pembakaran mencapai $500^{\circ}-600^{\circ}$ Celcius serta dibakar pada udara terbuka.
\end{abstract}

Kata Kunci: Gua Bulu Sumi, Tembikar, Analisis Teknologi Laboratoris.

\section{PENDAHULUAN}

Gua Bulu Sumi merupakan tipe gua tebing yang terletak di Bukit Bitta, termasuk wilayah Kampung Sumpang Bita, Desa Balocci Baru, Kecamatan Balocci, Kabupaten Pangkep, Provinsi Sulawesi Selatan. Gua Bulu Sumi terletak pada 4'54'57,7' lintang selatan dan $119^{\circ} 38^{\prime} 42,1^{\prime \prime}$ bujur timur, dengan ketinggian 208 meter di atas permukaan air laut. Gua Bulu Sumi mempunyai ukuran Lebar 8,82 meter dan kedalaman 10,5 meter, gua ini berarah hadap baratlaut. Gua Bulu Sumi ditemukan lukisan cap tangan merah dengan teknik semprot, alat litik, moluska, tembikar (Intan dkk., 2006; BP3, 2011).

Lingkungan geologi Gua Bulu Sumi termasuk dalam satuan morfologi karst dengan stadia geomorfologi termasuk dalam kategori stadia Muda - Dewasa. Yang dimaksud dengan Stadia geomorfologi 


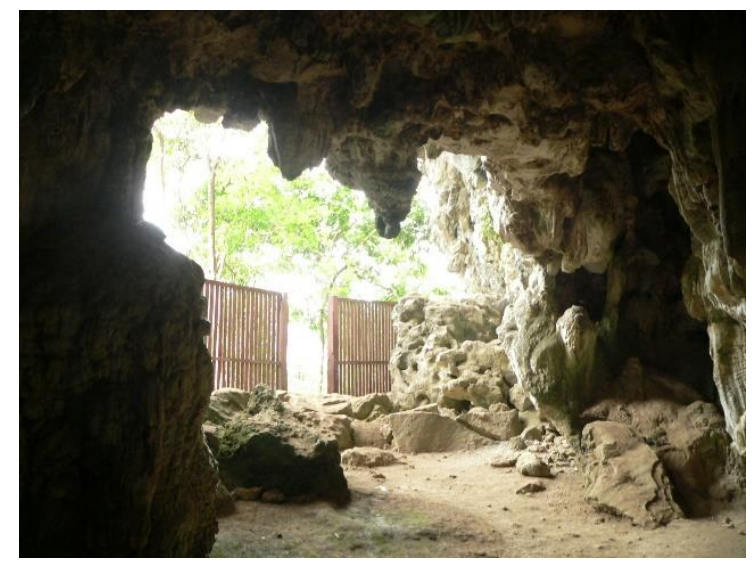

Gambar 1. Gua Bulu Sumi tampak dari dalam (Sumber: Dokumentasi Puslit Arkenas, tahun 2016)

adalah perwajahan permukaan bumi yang disebabkan oleh pengaruh tenaga eksogen. Stadia merupakan penggambaran umur relatif bentuk lahan tertentu yang dinyatakan dengan sebutan muda, dewasa, tua atau variasinya seperti muda awal, muda penuh, dewasa awal, dewasa akhir. Stadia suatu bentuk lahan dapat menjadi ukuran intensitas pengaruh tenaga perusak terhadap permukaan bumi ditempat itu. Pada stadia muda masih terlihat karakteristik asli bentuk lahan di suatu tempat, belum banyak mengalami proses perubahan (Lobeck, 1939; Thorbury, 1964).

Sungai yang ditemukan mengalir di sekitar wilayah gua ini adalah Sungai Mangemba (di utara) dan Sungai Padanglampe (di selatan) dengan pola aliran rectangular dan berstadia sungai dewasa. Pola rectangular adalah pola aliran sungai yang umumnya berkembang pada batuan yang resistensi terhadap erosinya mendekati seragam, namun dikontrol oleh sesar/patahan yang mempunyai dua arah dengan sudut saling tegak lurus. Pola aliran ini dijumpai di daerah yang wilayahnya terpatahkan (Lobeck, 1939; Thorbury, 1964).

Gua Bulu Sumi tersusun oleh batugamping yang berumur Eosen Awal hingga Miosen Tengah, dengan lingkungan pengendapan Neritik Dangkal hingga Laut Dalam dan Laguna (Soekamto, 1982). Gua
Bulu Sumi mengalami gangguan stuktur geologi berupa sesar/patahan (fault) yang melalui daerah penelitian termasuk pada jenis Sesar Normal (sesar turun)

dan Kekar (joint) (Billing, 1972) dan gua tersebut termasuk dalam kekar lembaran (sheet joint) (Intan, dkk., 2006). Yang dimaksud dengan patahan atau sesar (fault) adalah satu bentuk rekahan pada lapisan batuan bumi yg menyebabkan satu blok batuan bergerak relatif terhadap blok yang lain. Pergerakan bisa relatif turun, relatif naik, ataupun bergerak relatif mendatar terhadap blok yg lain. Sedangkan Kekar adalah suatu fracture (retakan pada batuan) yang relatif tidak mengalami pergeseran pada bidang rekahnya, yang disebabkan oleh gejala tektonik maupun non tektonik (Lobeck, 1939; Thorbury, 1964).

Secara umum vegetasi di Kompleks Situs Bita (Situs Gua Sumpang Bita dan Gua Bulu Sumi) terbagi atas a) Tumbuhan tingkat rendah yang biasa disebut juga dengan tumbuhan Pteridophyta merupakan jenis tumbuhan yang alat perkembangbiaknya berupa spora. Jenis tumbuhan yang tersebar di wilayah ini terdiri dari berbagai macam jenis antara lain: Selaginella, Drynaria, Neprolepis, Asplenium, Lindsaya, Pirrosia, Lycopodium, Adiantum, Pteris dan Drymoglosum; b) Tumbuh-tumbuhan tinggi yang biasa disebut juga dengan tumbuhan Spermatophyta banyak tersebar di wilayah ini (Intan, dkk., 2006).

Pemukiman adalah tempat dimana manusia melakukan segala macam kegiatannya. Untuk tetap dapat hidup melangsungkan kehidupannya, manusia secara langsung atau tidak, akan selalu tergantung pada lingkungan alam dan fisik tempatnya hidup. Akan tetapi pada hakekatnya, hubungan manusia dengan lingkungan alam dan fisiknya, tidaklah semata-mata terwujud sebagai hubungan ketergantungan manusia terhadap lingkungannya, tetapi juga terwujud sebagai 


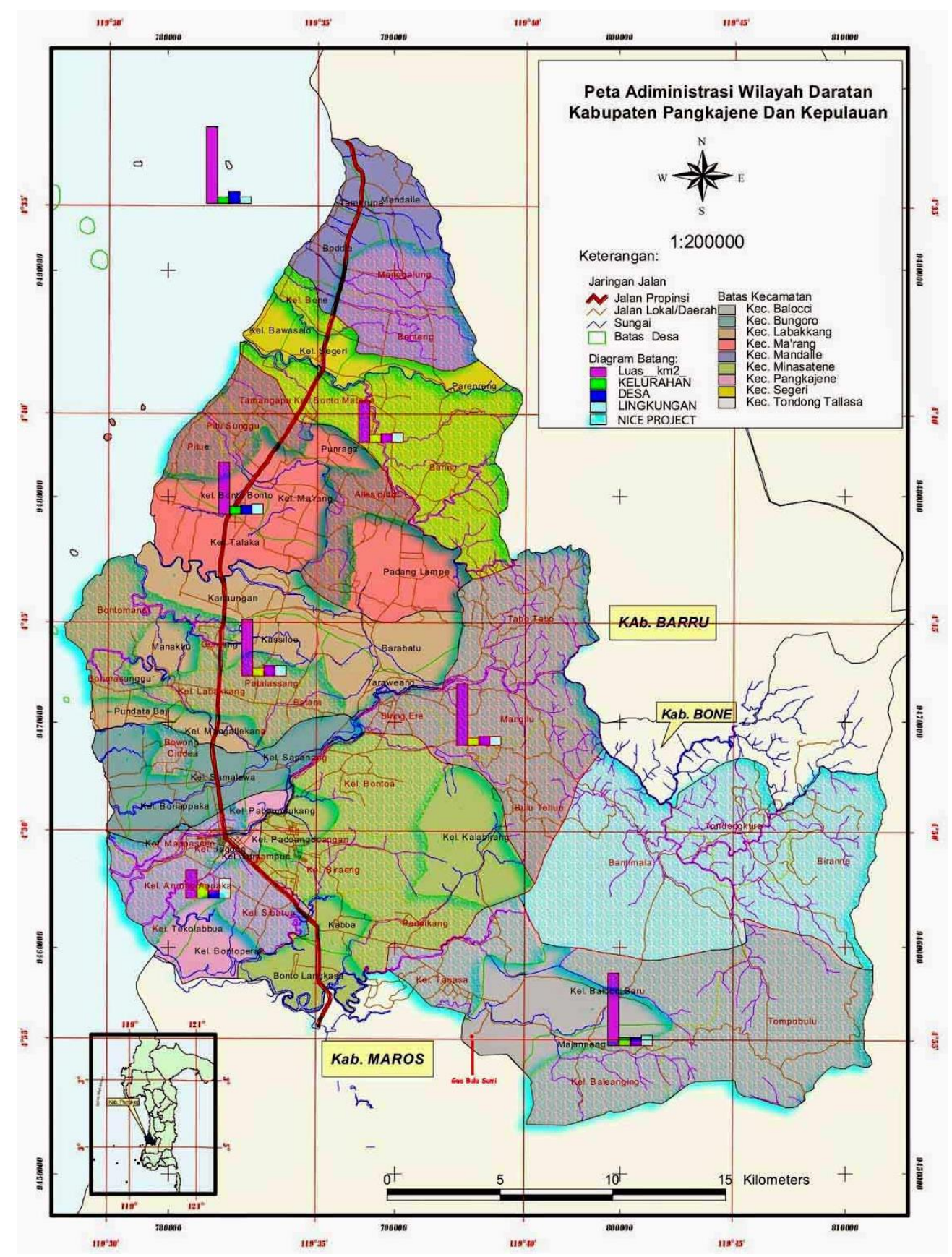

Gambar 2. Keletakan Gua Bulu Sumi dalam Peta Administrasi Wilayah Daratan Kabupaten Pangkejene dan Kepulauan

(Sumber: Dokumentasi BPS, Tahun 2016)

suatu hubungan dimana manusia mempengaruhi dan merubah lingkungannya.

Lingkungan alam dan fisik memberikan tantangan kepada manusia untuk dapat mempertahankan hidup. Sebagai jawaban terhadap tantangan lingkungan, manusia menciptakan kebudayaan (Yacob 1983, dalam Utomo,
1988). Dengan kebudayaan tadi manusia beradaptasi dengan lingkungannya. Dari lingkungan diperoleh makanan untuk dapat bertahan hidup, dan dari lingkungan pula manusia dapat membuat segala macam peralatan untuk berbagai kebutuhannya. Oleh karena itu, dengan meningkatnya peradaban manusia, maka tingkat kehidupan 


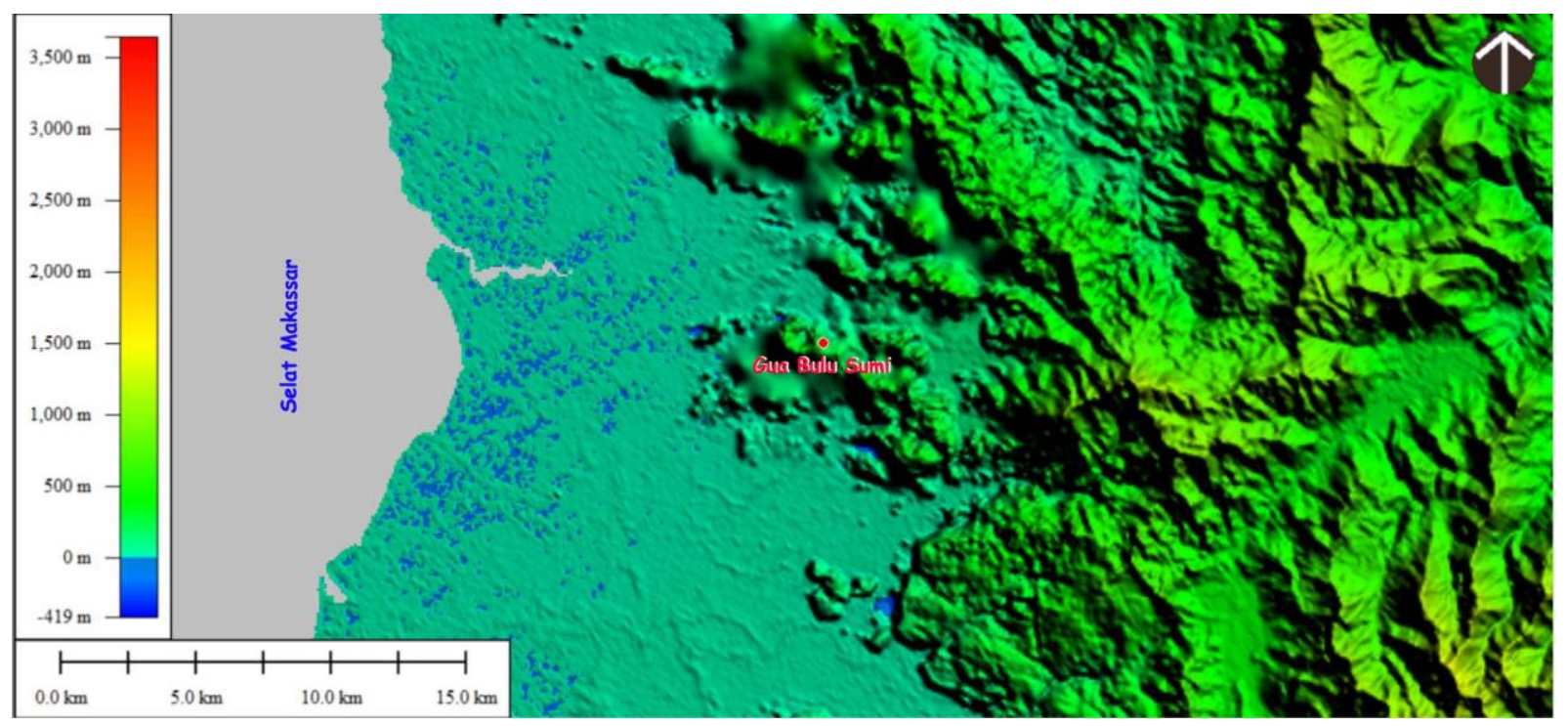

Gambar 3. Bentang alam dan keletakan Gua Bulu Sumi (Sumber: Data Topografi berdasarkan Jarvis et al. 2008)

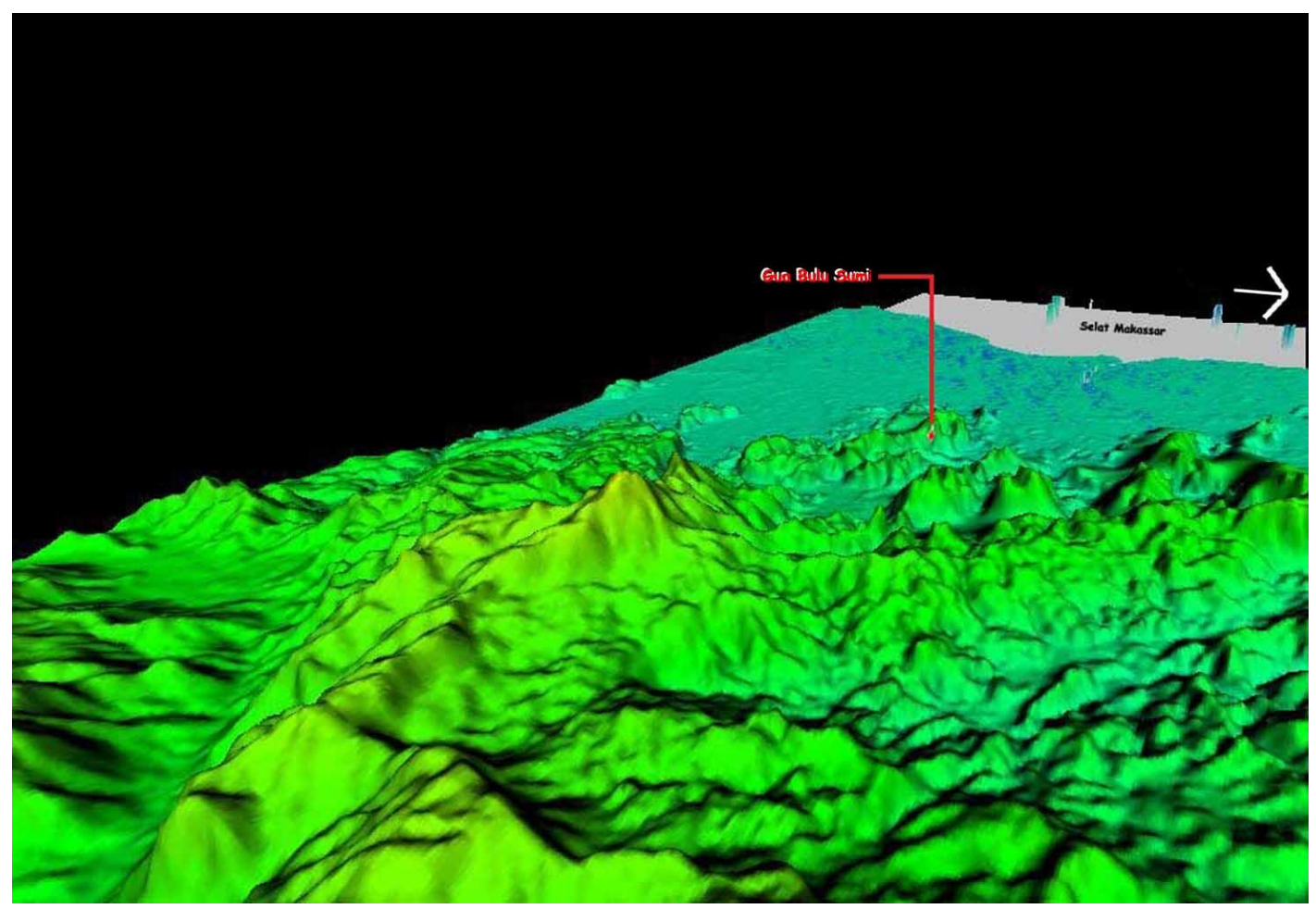

Gambar 4. Bentang alam dan keletakan Gua Bulu Sumi dalam bentuk tiga dimensi (Sumber: Data Topografi berdasarkan Jarvis et al. 2008)

dan kreativitas manusia dalam memenuhi kebutuhannya akan meningkat pula. Hal ini terlihat pada temuan-temuan dalam setiap penelitian arkeologi, bahan bakunya terbuat dari batu, kayu, dan tanah (Eriawati dkk., 1998). Tembikar merupakan salah satu sisa benda budaya yang paling sering ditemukan dalam penelitian arkeologi. Kajian terhadap aspek teknologis dari tembikar belum banyak dilakukan, selama ini lebih banyak dititikberatkan pada aspek bentuk dan aspek gaya (Soegondho, 1995). 


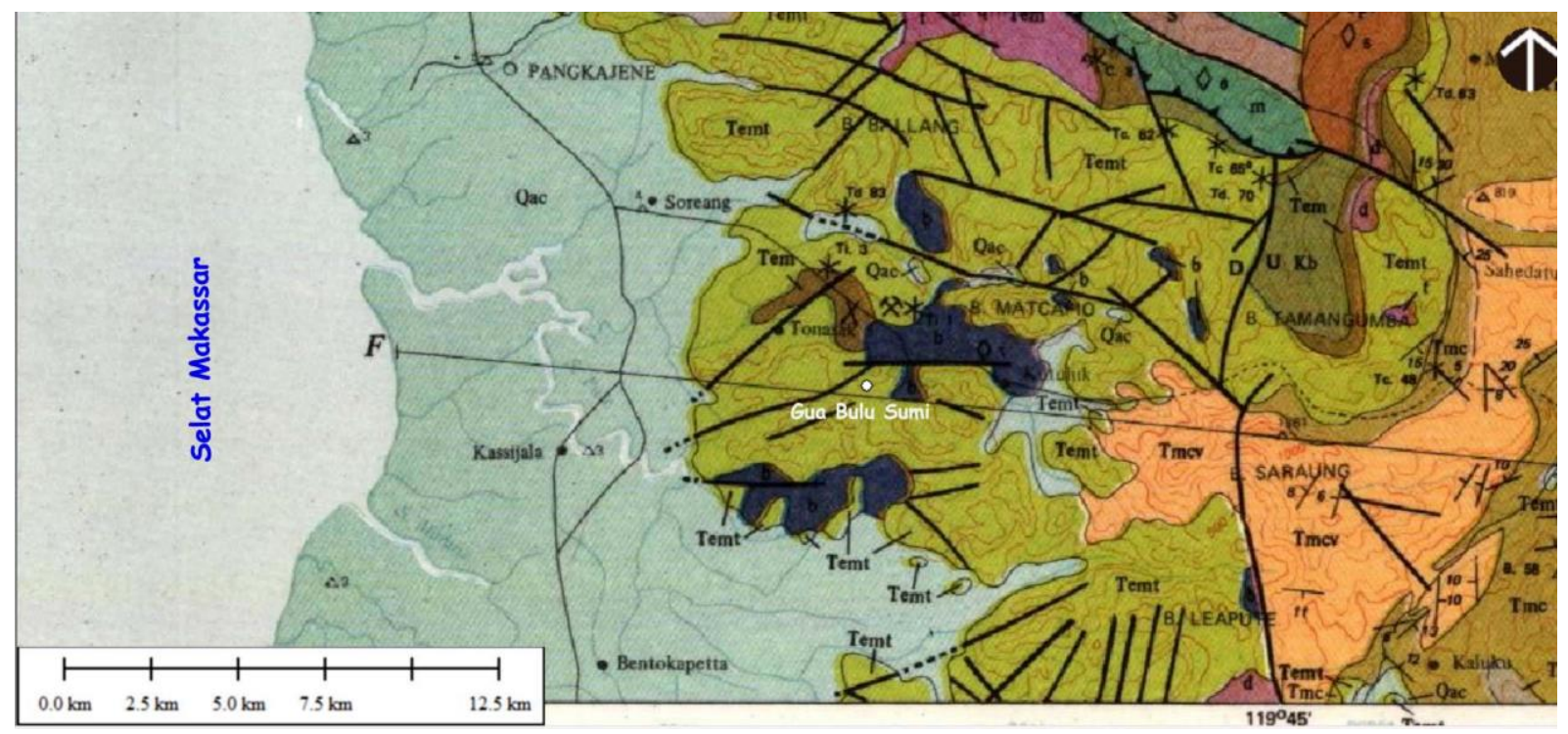

Gambar 5. Gua Bulu Sumi terletak pada Foramasi Tonasa dalam peta geologi

(Sumber: Dokumentasi Soekamto Rab, Tahun 1982)

Tembikar dibuat menurut cara-cara tradisional dengan menggunakan tanah liat sebagai bahan bakunya, kemudian dibakar pada temperatur tertentu hingga dianggap matang. Tembikar memegang peranan penting dalam kehidupan masyarakat masa lampau, baik dalam kehidupan sosial maupun dalam kehidupan religius (Soegondho 1995). Dalam kehidupan sosial ekonomi, tembikar merupakan perlengkapan kehidupan sehari-hari, misalnya menyimpan air, atau makanan, serta memasak atau mengawetkan bahan makanan. Dalam kehidupan religi, tembikar sering dipakai sebagai bekal kubur (buril gift) atau sebagai wadah kubur yang disebut dengan kubur tempayan (jar burial) (Soegondho 1995; Soegondho, 2000:3-10). Tembikar yang ditemukan dalam penelitian arkeologi menunjukkan ragam dan fungsinya, baik sebagai peralatan sehari-hari maupun sebagai peralatan religi (Wibisono, 2000:1318).

Jenis-jenis tembikar untuk kehidupan sehari-hari adalah berupa unsur bangunan, perangkat rumah tangga, dan alat produksi. Unsur bangunan dari tembikar adalah bata kuno, genteng, bubungan, momolo, tiang semu, ubin, dan miniatur rumah, kolam air, terowongan air, pipa saluran air dan dinding sumur (jobong). Perangkat rumah tangga sehari-hari dari tembikar yang berfungsi untuk menampung air (tempayan, buyung, jambangan, pasu, bak air), untuk mengolah makanan (periuk, kuali tutup, anglo, dan tungku), untuk penyajian makanan dan minuman (mangkuk, piring, teko dan kendi). Tembikar juga berfungsi sebagai alat untuk penerangan yaitu pelita (clupak). Selain itu, berbagai jenis figuratif dari tembikar seperti miniatur bangunan, manusia, dan binatang dipakai sebagai hiasan dengan berbagai ekspresi yang sangat dinamis, misalnya dalam hal berpakaian, menata rambut, pemakaian perhiasan (Wibisono, 2000:1318).

Tembikar sebagai alat produksi, sekalipun tidak banyak jenisnya tetapi dapat dicatat jenis benda terakota yang dibuat untuk kebutuhan produksi. Salah satu diantaranya adalah wadah pelebur logam. Bentuknya menterupai bejana silindrik berdasar bulat, bagian tepian terdapat lekukan untuk saluran menuang, dinding wadah ini sangat berpori, dinding sebelah luar biasanya terdapat lapisan lelehan kuarsa berwarna merah, hijau, atau hitam sebagai 
akibat dari sentuhan panas tinggi. Jenis alat produksi lainnya adalah cetakan tanah liat, yang menyerupai alat untuk menduplikasi bentuk-bentuk figuratif tanah liat tertentu. Adakalanya cetakan tanah liat digunakan untuk membuat model dari lilin yang ada kaitannya dengan proses pengecoran logam (Wibisono, 2000:13-18). Penggunaan tembikar juga digunakan untuk tujuan ritual keagamaan, yaitu stupika (terbuat dari tanah liat biasanya tidak dibakar), bagian dalam dari stupika terdapat tablet (terbuat dari tanah liat) yang ditulisi mantra budhis Selain stupika dan tablet, ternyata kendi (kundika atau kamandalu) juga dipergunakan dalam ritual keagamaan (Wibisono, 2000:13-18).

Berdasarkan pada permasalahan diatas, maka analisis teknologi laboratoris tembikar dari Situs Gua Biulu Sumi, bertujuan untuk memperoleh data yang akurat tentang fungsi dan kualitas dari tembikar.

\section{METODE PENELITIAN}

Metode penelitian yang digunakan dalam penelitian ini, dilakukan dengan beberapa tahap yaitu,

a. Kajian Pustaka, dilakukan dengan mempelajari lokasi penelitian dari peneliti terdahulu baik buku, jurnal, maupun internet.

b. Pengambilan dan pemilihan sampel tembikar. Sampel tembikar yang di analisis di laboratorium, berasal dari hasil penelitian di Gua Bulu Sumi yaitu: a) temuan permukaan, berupa fragmen tembikar, dasar, tebal, polos, halus; b) temuan dari BSM/TP/Spit-1/06 berupa fragmen tembikar, badan, tebal, polos, halus dan; c) temuan dari BSM/TP/Spit2/06 berupa fragmen tembikar, badan, tebal, polos, halus.

c. Sampel tembikar di analisis di laboratorium melalui analisis teknologi laboratoris. Analisis secara fisik meliputi kadar air, kekerasan, porositas, berat jenis, bahan dasar (lempung), bahan campuran (pasir), ukuran butir bahan dasar (lempung), ukuran butir bahan campuran (pasir), tingkat pembakaran, dan analisis mineralogi untuk mengetahui komposisi mineral dan non mineral yang dikandung oleh setiap sampel tembikar. Sedangkan analisis secara kimia menggunakan metode gravimetri, jenis unsur yang akan ditentukan dipisahkan dari senyawanya baik dalam bentuk asli maupun dalam bentuk senyawa lain yang susunannya diketahui dengan pasti.

Melalui kajian analisis teknologi laboratoris, misalnya di Situs Kayu Agung, OKI, Sumatera Selatan (Rangkuti dkk. 1993), Situs Kolo-Kolo, Selayar, Sulawesi Selatan (Intan 1996), Situs Bayat, Klaten, Jawa Tengah (Eriawati dkk. 2001), Situs Gedung Karya, Sumatera Selatan (Eriawati dkk. 1998; Astiti Komang Ayu, 1999), Situs Gua Rammang-Rammang, Maros, Sulawesi Selatan (Intan 2002), Situs Labo Tuo, Barus, Sumatera Utara (Sofyan dkk. 2006), Situs Karang Agung, Muba, Sumatera Selatan (Intan 2003a), Situs Leran, Gresik, Jawa Timur (Intan 2003b), Situs Megalitik Lembah Besoa, Sulawesi Tengah (Sofyan dkk. 2003), Situs Minanga Sipakko, Mamuju, Sulawesi Barat (Intan 2011), dan Situs-Situs Das Bengawan Solo Kabupaten Bojonegoro, Jawa Timur (Intan 2015), telah dapat ditentukan baik kualitas maupun fungsi dari tembikar yang dibuat oleh para pengrajin pada masa lampau.

\section{HASIL DAN PEMBAHASAN}

\section{Analisis Laboratoris}

Analisis laboratoris tembikar dari Situs Gua Bulu Sumi yang dilaksanakan dengan metode fisik dan kimia, adalah sebagai berikut:

\section{a. Analisis Fisik}

Analisis secara fisik meliputi kadar air, kekerasan, porositas, berat jenis, bahan dasar (lempung), bahan campuran (pasir), ukuran butir bahan dasar (lempung), ukuran butir bahan campuran (pasir), tingkat 
Tabel 1. Hasil Analisis Laboratoris (Kimia) Tembikar Dari Situs-Gua Bulu Sumi, Pangkep

\begin{tabular}{|c|c|c|c|c|c|c|c|}
\hline \multirow{2}{*}{$\begin{array}{c}\text { No. } \\
\text { Sampel }\end{array}$} & \multirow[b]{2}{*}{$\begin{array}{c}\text { Sampel } \\
\text { Fragmen }\end{array}$} & \multicolumn{6}{|c|}{ Kandungan Unsur (\%) } \\
\hline & & $\begin{array}{l}\text { Silikat } \\
\left(\mathrm{SiO}_{2}\right)\end{array}$ & $\begin{array}{l}\text { Besi } \\
\text { (Fe) }\end{array}$ & $\begin{array}{c}\text { Kapur } \\
\left(\mathrm{CaCO}_{3}\right)\end{array}$ & $\begin{array}{c}\text { Magnesium } \\
\text { (Mg) }\end{array}$ & $\begin{array}{l}\log \text { of } \\
\text { Ignation } \\
\text { (LOI) }\end{array}$ & $\begin{array}{c}\text { Unsur } \\
\text { Lain }\end{array}$ \\
\hline 1 & $\begin{array}{l}\text { Temuan permukaan, } \\
\text { berupa fragmen } \\
\text { tembikar, dasar, tebal, } \\
\text { polos, halus }\end{array}$ & 68 & 0,39 & 4 & 1 & 11,86 & 14,75 \\
\hline 2 & $\begin{array}{c}\text { Temuan dari } \\
\text { BSM/TP/Spit-1/06, } \\
\text { berupa fragmen } \\
\text { tembikar, badan, } \\
\text { tebal, polos, halus }\end{array}$ & 67 & 0,43 & 4 & 1 & 14,5 & 13,07 \\
\hline 3 & $\begin{array}{c}\text { Temuan dari } \\
\text { BSM/TP/Spit-2/06, } \\
\text { berupa fragmen } \\
\text { tembikar, badan, } \\
\text { tebal, polos, halus }\end{array}$ & 60,75 & 0,39 & 4 & 1,5 & 12,36 & 21,08 \\
\hline
\end{tabular}

(Sumber: diolah dari data analisis kimia/gravimetri)

pembakaran dan analisis mineralogi untuk mengetahui komposisi mineral dan non mineral yang dikandung oleh setiap sampel tembikar. Hasil analisis teknologi laboratoris tembikar dari Situs Gua Bulu Sumi dengan metode analisis fisik adalah sebagai berikut (Tabel-1 terlampir):

1) Temuan permukaan, berupa fragmen tembikar, dasar, tebal, polos, halus. Berwarna coklat kemerahan (5/410YR), berat sampel 4,34 gram, tebal 9,11 mm, dengan kekerasan 3,5 skala Mohs. Berat jenis 2,52 dengan porositas $31,72 \%$ serta daya serap air $15,55 \%$, kadar air $1,15 \%$ dan $\log$ of ignation (LOI) 3,24\%. Komposisi bahan baku utama (lempung) 60\%, bahan baku tambahan (pasir) 40\%, dengan ukuran butir lempung 0,0033-0,0400 $\mathrm{mm}$ dan pasir berukuran butir 0,0384-0,0555 mm (Pettijohn, 1975). Tingkat pembakaran tembikar tersebut adalah $500^{\circ}-600^{\circ}$ Celcius. Komposisi mineral adalah kuarsa, plagioklas, hornblende, piroksen, pirit, dan lempung, sedangkan komposisi non mineral adalah fragmen batuan beku (Kraus et.al., 1959; Ong dkk., 1981).
2) Temuan dari BSM/TP/Spit-1/06, berupa fragmen tembikar, badan, tebal, polos, halus. Berwarna coklat (5/4-7,5YR), berat sampel 5,79 gram, tebal 7,91 mm, dengan kekerasan 3,5 skala Mohs. Berat jenis 2,63 dengan porositas 37,01\% serta daya serap air $18,23 \%$, kadar air $3,97 \%$ dan log of ignation (LOI) $5,31 \%$. Komposisi bahan baku utama (lempung) 65\%, bahan baku tambahan (pasir) 35\%, dengan ukuran butir lempung 0,0033-0,0400 $\mathrm{mm}$ dan pasir berukuran butir 0,0384-0,0555 mm (Pettijohn, 1975). Tingkat pembakaran tembikar tersebut adalah $500^{\circ}-600^{\circ}$ Celcius. Komposisi mineral adalah kuarsa, plagioklas, hornblende, piroksen, pirit, dan lempung, sedangkan komposisi non mineral adalah fragmen batuan beku. (Kraus et.al., 1959; Ong dkk., 1981).

3) Temuan dari BSM/TP/Spit-2/06, berupa fragmen tembikar, badan, tebal, polos, halus. Berwarna abu-abu (5/1-7,5YR), berat sampel 3,33 gram, tebal 5,89 mm, dengan kekerasan 3,5 skala Mohs. Berat jenis 2,58 dengan porositas 34,04\% serta daya serap air $16,62 \%$, kadar air $3,60 \%$ dan log of ignation (LOI) $9,37 \%$. 
Komposisi bahan baku utama (lempung) 60\%, bahan baku tambahan (pasir) 40\%, dengan ukuran butir lempung 0,0033-0,0400 $\mathrm{mm}$ dan pasir berukuran butir $0,0384-0,0555 \mathrm{~mm}$ (Pettijohn, 1975). Tingkat pembakaran tembikar tersebut adalah $500^{\circ}-600^{\circ}$ Celcius. Komposisi mineral adalah kuarsa, plagioklas, hornblende, piroksen, pirit, dan lempung, sedangkan komposisi non mineral adalah fragmen batuan beku (Kraus et.al., 1959; Ong dkk., 1981).

Dari analisis fisik tembikar, didapatkan data-sebagai berikut, kekerasan (hardness) tembikar adalah 3,5 Skala Mohs, dengan berat jenis 2,52-2,63 serta porositas $31,72 \%-37,01 \%$ dan daya serap air $15,15 \%$ $18,23 \%$, kadar air 1,15\%-3,97\% dan log of ignation (LOI) 3,24\%-9,37\%. Perbandingan komposisi bahan baku tembikar, yaitu bahan baku utama (lempung) 60\%-65\%, sedangkan bahan baku tambahan (pasir) 35\%-40\%. Lempung sebagai bahan baku utama berukuran butir antara $0,0033 \mathrm{~mm}$ hingga $0,0400 \mathrm{~mm}$, sedangkan pasir berukuran butir antara $0,0384 \mathrm{~mm}$ hingga $0,0555 \mathrm{~mm}$. Komposisi mineral dari setiap fragmen tembikar umumnya adalah kuarsa, plagioklas, hornblende, piroksen, pirit, dan lempung, sedangkan komposisi non mineral adalah fragmen batuan beku. Tingkat pembakaran tembikar mencapai $500^{\circ}-600^{\circ}$ Celcius, yang dibakar pada udara terbuka (open air baked). Warna dari tembikartembikar dari Gua Bulu Sumi yang di analisis tersebut didominasi warna terang (light colors) dibanding dengan warna gelap (dark colors). Warna terang pada tembikar disebabkan oleh kandungan mineral kuarsa, dan plagioklas pada bahan baku, sedangkan warna gelap pada tembikar disebabkan oleh kandungan mineral piroksen, dan hornblende pada bahan baku (Ong H.L. dkk., 1981; Pettijohn P.J. 1975).

\section{b. Analisis Kimia}

Analisis secara kimia menggunakan metode gravimetri, jenis unsur yang akan ditentukan dipisahkan dari senyawanya baik dalam bentuk asli maupun dalam bentuk senyawa lain yang susunannya diketahui dengan pasti. Hasil analisis teknologi laboratoris tembikar dari Situs Gua Bulu Sumi dengan metode analisis kimia adalah sebagai berikut (Tabel 1):

1) Temuan permukaan, berupa fragmen tembikar, dasar, tebal, polos, halus. Hasil analisis kimia mengandung silikat $\left(\mathrm{SiO}_{2}\right) 68 \%$, besi $(\mathrm{Fe}) 0,39 \%$, kapur $\left(\mathrm{CaCO}_{3}\right) 4 \%$, Magnesium $(\mathrm{Mg}) 1 \%, \log$ of ignation (LOI) $11,86 \%$, dan unsurunsur lain 14,75\%.

2) Temuan dari BSM/TP/Spit-1/06, berupa fragmen tembikar, badan, tebal, polos, halus. Hasil analisis kimia mengandung silikat $\left(\mathrm{SiO}_{2}\right) 67 \%$, besi (Fe) 0,43\%, kapur $\left(\mathrm{CaCO}_{3}\right) 4 \%$, Magnesium $(\mathrm{Mg})$ $1 \%, \log$ of ignation (LOI) $14,5 \%$, dan unsur-unsur lain 13,07\%.

3) Temuan dari BSM/TP/Spit-2/06, berupa fragmen tembikar, badan, tebal, polos, halus. Hasil analisis kimia mengandung silikat $\left(\mathrm{SiO}_{2}\right) 60,75 \%$, besi $(\mathrm{Fe})$ 0,39\%, kapur $\left(\mathrm{CaCO}_{3}\right) 4 \%$, Magnesium $(\mathrm{Mg})$ $1,5 \%, \log$ of ignation (LOI) $12,36 \%$, dan unsur-unsur lain 21,08\%.

Dari hasil analisis kimia, diperoleh 4 unsur kimia, yaitu $\mathrm{Si}, \mathrm{Fe}, \mathrm{Ca}$, dan $\mathrm{Mg}$. dari keempat unsur tersebut, maka unsur $\mathrm{Si}$ menduduki tempat pertama dengan prosentase 57,5-68\%, disusul $\mathrm{Ca}$ 4-4,5\%, Mg 1-2\%, dan Fe 0,36-0,44\%. Dari keempat unsur tersebut, tidak dimasukkan hilang bakar (LOI) sebesar 9,5-14,5\%, dan unsurunsur lain yang tidak terdeteksi sebesar $13,07-25,06 \%$.

\section{Kualitas Tembikar}

Berdasarkan hasil analisis teknologi laboratoris tembikar (fisik dan kimia), maka dapat dijelaskan tentang kualitas dari tembikartembikar yang ditemukan di Situs Gua Bulu Sumi, Pangkep, dengan menggunakan acuan yang diajukan oleh Soegondho (1993) (Tabel 2). 
Tabel 2. Acuan Penentu Kualitas Tembikar

\begin{tabular}{ccccc}
\hline No & Pengukuran & Buruk & Sedang & Baik \\
\hline 1 & Berat Jenis & $1-1,90 \mathrm{~g} / \mathrm{cm} 3$ & $2-3,5 \mathrm{~g} / \mathrm{cm} 3$ & Diatas 3,5 g/cm3 \\
\hline 2 & Kekerasan & $\begin{array}{c}\text { Dibawah 3 Skala } \\
\text { Mohs }\end{array}$ & $3-3,5$ Skala Mohs & Diatas $>3,5$ Skala Mohs \\
\hline 3 & Porositas & Diatas 50\% & $40-50 \%$ & Dibawah $40 \%$ \\
\hline
\end{tabular}

(Sumber: Soegondho 1993:337)

a. Temuan permukaan berupa fragmen tembikar, dasar, polos, tebal, halus. Tiga aspek dari sifat fisik tembikar halus yaitu kekerasan 3,5 skala Mohs, berat jenis 2,52 dan porositas $31,72 \%$, yang apabila dibandingkan dengan acuan dari Santoso (1993), maka kualitas tembikar ermasuk pada Kualitas Sedang, didasarkan pada berat jenis $(2,52$ $\left.\mathrm{g} / \mathrm{cm}^{3}\right)$, Kualitas Baik, berdasarkan pada porositas $(31,72 \%)$, dan Kualitas Sedang, berdasarkan pada kekerasan (3,5 skala Mohs).

b. BSM/TP1/Spit-1/06 berupa fragmen tembikar badan, polos, tebal, halus. Tiga aspek dari sifat fisik tembikar halus yaitu kekerasan 3,5 skala Mohs, berat jenis 2,63 dan porositas $37,01 \%$, yang apabila dibandingkan dengan acuan dari Santoso (1993), maka kualitas tembikar termasuk pada Kualitas Sedang, didasarkan pada berat jenis $(2,63$ $\left.\mathrm{g} / \mathrm{cm}^{3}\right)$, Kualitas Baik, berdasarkan pada porositas $(37,01 \%)$, dan Kualitas Sedang, berdasarkan pada kekerasan (3,5 skala Mohs).

c. BSM/TP/Spit-2/06 berupa fragmen tembikar badan, polos, tebal, halus. Tiga aspek dari sifat fisik tembikar halus yaitu kekerasan 3,5 skala Mohs, berat jenis 2,58 dan porositas 34,04\%, yang apabila dibandingkan dengan acuan dari Soegondo (1993), maka kualitas tembikar termasuk pada Kualitas Sedang, didasarkan pada berat jenis $\left(2,58 \mathrm{~g} / \mathrm{cm}^{3}\right) . \quad$ Kualitas Baik, berdasarkan pada porositas $(34,04 \%)$.
Kualitas Sedang, berdasarkan pada kekerasan (3,5 skala Mohs).

\section{PENUTUP}

Dari hasil analisis teknologi laboratoris tembikar dari Situs Gua Bulu Sumi, Pangkep, dapat disimpulkan bahwa tembikar-tembikar mempunyai kualitas sedang hingga kualitas baik, serta dikategorikan kedalam peralatan sehari-hari yang berfungsi untuk menampung air (tempayan, buyung, jambangan, pasu, bak air), untuk mengolah makanan (periuk, kuali tutup, anglo, dan tungku), untuk penyajian makanan dan minuman (mangkuk, piring, teko dan kendi).

Tingkat pembakaran tembikar mencapai $500^{\circ}-600^{\circ}$ Celcius, dan dibakar pada udara terbuka (open air baked). Warna dari fragmen-fragmen tembikar tersebut didominasi oleh warna terang (light colors) bila dibandingkan dengan warna gelap (dark colors). Warna terang (light colors) pada tembikar disebabkan oleh kandungan mineral kuarsa, dan plagioklas pada bahan baku. Adanya perbedaan prosentase dari setiap unsur kimia pada tembikar tersebut, tidak terlepas dari daya tahan mineral dari terhadap pelapukan, misalnya mineral yang paling tahan terhadap pelapukan adalah kuarsa (SiO2), sehingga mineral kuarsa ini paling sering ditemukan pada sedimen lempung, sedangkan mineral yang paling tidak tahan terhadap pelapukan adalah mineral-mineral yang pertama menghablur atau mengkristal, contohnya mineral olivin dan mineral Anortiit (Kraus et.al., 1959). 


\section{DAFTAR PUSTAKA}

Astiti Komang Ayu, 1999. Analisis Sifat-Sifat Fisik Dan Unsur-Unsur Kimia Beberapa Tembikar Situs Gedungkarya, Muara Jambi, Sumatera Selatan. Laporan Penelitian Arkeologi Bidang Arkeometri, Pusat Penelitian Arkeologi Nasional.

Billing, M.P. 1972. Structural Geology. Prentice-Hall, Inc. Englewood Cliggs, New Jersey.

BP3 Makassar, 2011. Zonasi Gua-Gua Prasejarah Kabupaten Pangkep 2011. Balai Pelestarian Peninggalan Purbakala Makassar.

BPS, 2016. Kabupaten Pangkajene Dan Kepulauan Dalam Angka. Badan Pusat Statistik, Kabupaten Pangkajene Dan Kepulauan.

Eriawati Yusmaini, Intan S. Fadhlan M. 1998. "Kendi Tembikar Situs Gedungkarya: Gambaran Tingkat Keterampilan Penganjun Lokal”. Siddhayatra, Balai Arkeologi Palembang, Jurnal Arkeologi 3 (2): hal. 1-14.

Eriawati Yusmaini, Intan S. Fadhlan M., Lelono Harry, 2001 Studi Etnoarkeologi: Pola Tata Kerja dan Tata Ruang Kerja Pengrajin Tembikar di Kec. Bayat, Kab. Klaten, Prov. Jawa Tengah. Laporan Penelitian Arkeologi Bidang Program, Sub Bidang Arkeometri, Pusat Penelitian Arkeologi. Jakarta.

Intan S. Fadhlan M. 1996. Industri Tembikar Di Kolo-Kolo, Selayar. Majalah Kebudayaan , Nomor 12, Tahun VI 1996/1997: hal: 74-82.

Intan S. Fadhlan M. 2002 Analisis Teknologi Laboratoris Gerabah Situs Gua RammangRammang, Maros, Sulawesi Selatan” Walennae Jurnal Arkeologi Sulselra, Volume V, Nomor 8, Balai Arkeologi Makassar.

Intan S. Fadhlan M. 2003a. Gerabah Situs Karang Agung: Analisis Teknologi Laboratoris. Siddhayatra, Balai Arkeologi Palembang, Jurnal Arkeologi, No. 1 Vol.8, Mei 2003

Intan S. Fadhlan M. 2003b. Analisis Teknologi Laboratoris Gerabah dari Situs Leran. Berkala Arkeologi, Balai Arkeologi Yogyakarta, Tahun XXIII, Edisi No.1, Mei 2003

Intan S. Fadhlan M., Vita, Nasruddin, 2006 Lingkungan Dan Tinggalan Arkeologi Di Kompleks Situs Bita Kabupaten Pangkep, Provinsi Sulawesi Selatan. Puslitbang Arkenas. Departemen Kebudayaan Dan Pariwisata

Intan S. Fadhlan M., 2011. Analisis Teknologi Laboratoris Tembikar Dari Situs Minanga Sipakko, Kec. Kalumpang, Kab. Mamuju, Prov. Sulawesi Barat. Kalpataru, Majalah Arkeologi, Vol. 20 No. 1 - Maret 2011. Pusat Penelitian dan Pengembangan Arkeologi Nasional. Kementerian Kebudayaan Dan Pariwisata.

Intan S. Fadhlan M., 2015. Analisis Teknologi Laboratoris Tembikar Dari Situs-situs DAS Bengawan Solo, Kabupaten Bojonegoro, Provinsi Jawa Timur Barat”. Kalpataru, Majalah Arkeologi, Vol. 24 No. 1 - Mei 2015. Pusat Penelitian Arkeologi Nasional. Kementerian Pendidikan Dan Kebudayaan. 
Jarvis, A., H.I. Reuter, A. Nelson, dan E. Guevara. 2008 Hole-filled seamless SRTM data V4. Center for Tropical Agliculture (CIAT).

Kraus, Hunt, Ramsdell, 1959 Mineralogy, An Introduction to the Study of Minerals and Crystals. McGraw-Hill Book Company, Inc. New York, Toronto, London, Kogakusha Company, Ltd. Tokyo.

Lobeck, A.K., 1939, Geomorphology, An Introduction To The Study of Landscape. Mc Graw Hill Book Company Inc, New York and London.

Ong, H.L. dkk, 1981 Mineralogi. Laboratorium Mineralogi, Departemen Teknik Geologi ITB, Bandung.

Pettijohn, P.J., 1975. Sedimentary Rocks. New York, Harper and Brothers.

Rangkuti N., dan Intan S. Fadhlan M.. 1993. “Tembikar Tradisi Sriwijaya Di Kayu Agung”. SRIWIJAYA dalam perspektif arkeologi dan sejarah. Editor: Faizaliskandiar Mindra, Wibisono Sonny, dan Hanafiah Johan. Pemda Tk. I Sumatera Selatan, hal: C7 1-14.

Soegondho, Santoso, 1993 Wadah Keramik Tanah Liat Dari Gilimanuk dan Plawangan: Sebuah Kajian Teknologi dan Fungsi. Disertasi Bidang Ilmu Pengetahuan Budaya, Program Pascasarjana, Universitas Indonesia.

Soegondho Santoso, 1995 Tradisi Tembikar Di Indonesia: Dari Masa Prasejarah Hingga Masa Kini. Jakarta : P.T Dian Rakyat.

Soegondho Santoso, 2000 Terakota Masa Prasejarah. dalam buku 3000 Tahun Terakota Indonesia: Jejak Tanah dan Api. Museum Nasional Indonesia, Jakarta, hal: 3-10.

Soekamto, Rab., 1982 Geologi Lembar Pangkajene dan Watampone Bagian Barat, Sulawesi. P3G, Bandung.

Sofyan Arfian, Intan S. Fadhlan M. 2003. "Analisis Laboratoris Temuan Gerabah dari Situs Megalitik Lembah Besoa". Jejak-Jejak ARKEOLOGI, Balai Arkeologi Manado, Bulletin Nomor 6, Tahun 2006

Sofyan Arfian, Intan S. Fadhlan M. 2006. "Analisis Teknologi Temuan Gerabah Kuno di Situs Labo Tua". AMERTA Berkala Arkeologi, Asisten Deputi Urusan Arkeologi Nasional, No. 23 Tahun 2004.

Thornbury, W.D., 1964 Principle of Geomorphology. New York, London, John Wiley And Sons, inc.

Utomo, B. Budi, 1988 Permasalahan Umum Arkeologi Jambi. REHPA III, Pandeglang, 5-9 Desember 1986, Puslit Arkenas, Depdikbud.

Wibisono, S., 2000 Terakota Masa Klasik. dalam buku 3000 Tahun Terakota Indonesia: Jejak Tanah dan Api. Museum Nasional Indonesia, Jakarta, hal: 13-18. 


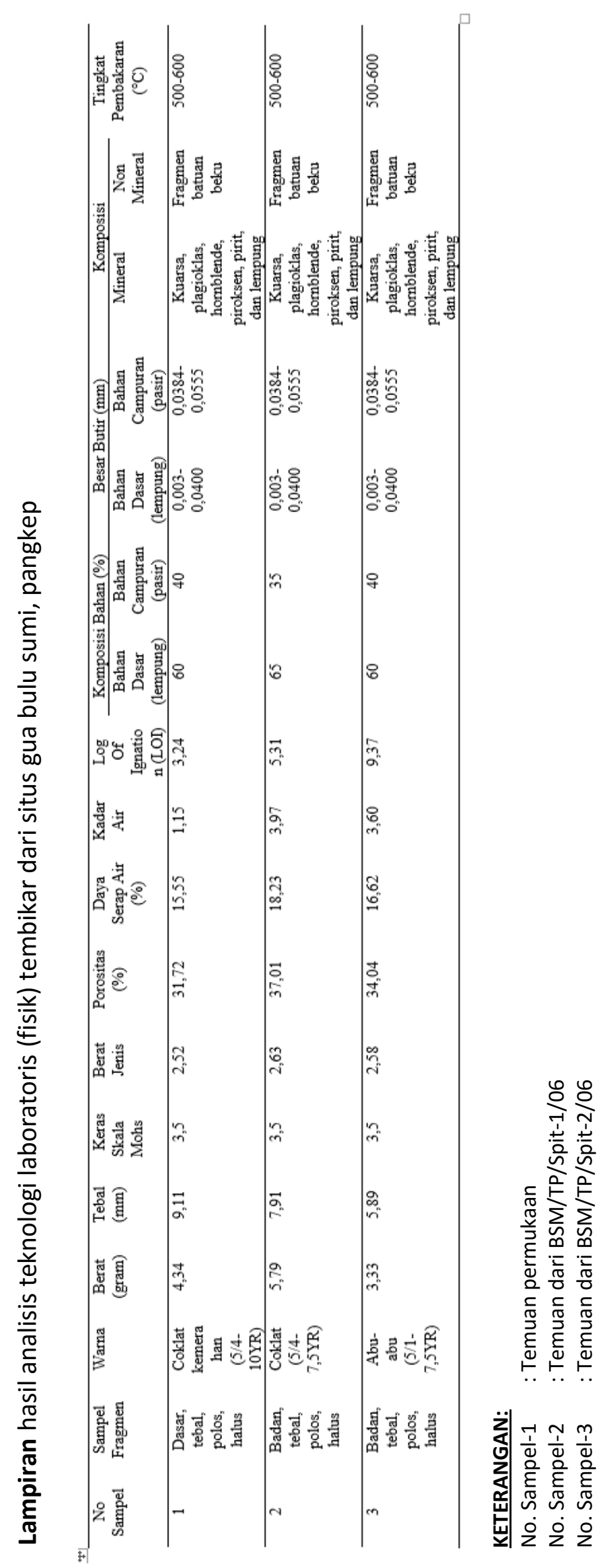

